Article

\title{
Beyond Sufficiency: G.A. Cohen's Community Constraint on Luck Egalitarianism
}

Benjamin D. King

\begin{abstract}
G.A. Cohen conceptualizes socialism as luck egalitarianism constrained by a community principle. The latter mitigates certain inequalities to achieve a shared common life. This article explores the plausibility of the community constraint on inequality in light of two related problems. First, if it is voluntary, it fails as a response to "the abandonment objection" to luck egalitarianism, as it would not guarantee imprudent people sufficient resources to avoid deprivation and to function as equal citizens in a democratic society. Contra Cohenite socialism, this appears unjust. Second, if it is instead enforced, coercive equalization beyond sufficiency-constrained luck egalitarianism, which is possibly necessary to achieve a shared common life, seems to require unjustified restrictions on liberty. I therefore argue that the constraint is most plausibly specified as requiring enforcement of sufficiency and only voluntary equalization thereafter. I also note, skeptically, why this constraint might be morally preferable to a purely sufficientarian alternative.
\end{abstract}

Keywords: G.A. Cohen, community, luck egalitarianism, sufficiency

\section{Introduction}

$\mathrm{I}$

n Why Not Socialism? G.A. Cohen attempts to defend the desirability and feasibility of a conception of socialism that is embodied by an egalitarian 1 principle and a community principle. The former Cohen calls "socialist equality of opportunity," which is more commonly known as "luck egalitarianism" and sometimes as "responsibility-sensitive egalitarianism." It "seeks to correct for all unchosen disadvantages, disadvantages, that is, for which the agent cannot herself reasonably be held responsible, whether they be disadvantages that reflect social misfortune or disadvantages that reflect

(C) 2018 Benjamin D. King

https://www.kritike.org/journal/issue 22/king june2018.pdf

ISSN 1908-7330

(cc) $\mathrm{BY}-\mathrm{NC}-\mathrm{ND}$ 


\section{BEYOND SUFFICIENCY}

natural misfortune." ${ }^{1}$ Thus, unlike in contemporary capitalist societies, where distributive shares are influenced by the socio-economic circumstances into which people are born and raised, as well as by differences in people's natural abilities and their market value, "[w]hen socialist equality of opportunity prevails, differences of outcome reflect nothing but differences of taste and choice," made against a background of equal options, for which people "may therefore reasonably be held responsible." 2

Socialist equality of opportunity is consistent with two forms of inequality. The first form of inequality occurs when people's different choices, such as about how many hours to work and how much to consume, result in inequalities of resources, yet the satisfaction of their different preferences "leads to a comparable aggregate enjoyment of life." 3 Cohen deems this form of inequality "unproblematic because it does not constitute an inequality, all things considered." 4 The second form of inequality comes in two subtypes, inequalities that occur due to "regrettable choice" and inequalities that occur due to "option luck." These subtypes are not mutually exclusive and both are problematic as they do involve inequality of aggregate benefit. Regrettable choice inequalities occur when people make genuine choices, for example, to expend less effort and/or care in examining their occupational opportunities, which they retrospectively regret due to the inequality of aggregate benefit they incur. ${ }^{5}$ Option luck inequalities are inequalities of aggregate benefit that result from people's genuine choices to participate in gambles that they either win or lose, and which losers might not necessarily regret if their chances of winning were reasonable. ${ }^{6}$

But why should we consider these inequalities problematic if people can reasonably be held responsible for their relative advantage or disadvantage? Cohen's worry is that they potentially undermine community. As he puts it:

Although [regrettable choice and/or option luck] inequalities ... are not condemned by justice [because

\footnotetext{
${ }^{1}$ G.A. Cohen, Why Not Socialism? (Princeton, NJ: Princeton University Press, 2009), 1718. See also G.A. Cohen, "On the Currency of Egalitarian Justice," in Ethics, 99:4 (1989).

${ }^{2}$ Cohen, Why Not Socialism? 18, 26. For a survey of the literature on luck egalitarianism, see Carl Knight, "Luck Egalitarianism," in Philosophy Compass, 8:10 (2013).

${ }^{3}$ Cohen, Why Not Socialism? 19.

${ }^{4}$ Ibid., 25.

${ }^{5}$ Ibid., 26-28.

${ }^{6}$ Ibid., 30-32. Influenced by Ronald Dworkin, luck egalitarians distinguish between "option luck" and "brute luck." As Dworkin draws the distinction in "What is Equality? Part 2: Equality of Resources," in Philosophy and Public Affairs, 10:4 (1981), 293: "Option luck is a matter of how deliberate and calculated gambles turn out-whether someone gains or loses through accepting an isolated risk he or she should have anticipated and might have declined. Brute luck is a matter of how risks fall out that are not in that sense deliberate gambles."
}

(c) 2018 Benjamin D. King

https://www.kritike.org/journal/issue 22/king june2018.pdf

ISSN 1908-7330

(c) BY-NC-ND 
they are responsibility-sensitive], they are nevertheless repugnant to socialists when they obtain on a sufficiently large scale, because they then contradict community: community is put under strain when large inequalities obtain. The sway of socialist equality of opportunity must therefore be tempered by a principle of community. ${ }^{7}$

This article explores the plausibility of Cohen's community constraint on luck egalitarianism, and in doing so reveals its demandingness compared to a more commonly embraced sufficiency constraint. I begin by clarifying that it requires resource sharing and avoidance of option luck that constrains the relevant inequalities to the extent that people share in a common life, understood as the lives of the worst off not laboring under many more challenges than those of the best off. This clarificatory task partly involves questioning some interpretations in the literature that associate the constraint with Cohen's concepts of "justificatory community" and "egalitarian ethos," which feature in his critique of John Rawls. Following this clarificatory work, I proceed to investigate the plausibility of the constraint in light of two related problems. First, if the constraint is voluntary, it fails as a response to "the abandonment objection" to luck egalitarianism, as it would not guarantee imprudent people sufficient resources to avoid deprivation and to function as equal citizens in a democratic society. Contra Cohenite socialism, this appears unjust. Second, if the constraint is instead enforced, coercive equalization of resources beyond sufficiency-constrained luck egalitarianism, which is possibly necessary to achieve a shared common life, seems to require unjustified restrictions on liberty. I therefore argue that the community constraint is most plausibly specified as requiring enforcement of sufficiency and only voluntary equalization of resources thereafter. I finish by briefly noting, with some skepticism, two possible reasons why this version of the constraint might be morally preferable to a purely sufficientarian alternative.

\section{The Community Constraint}

Cohen describes the community principle in terms of "two modes of communal caring." 8 The second type of caring, which he calls "communal reciprocity," involves human relationships taking a certain desirable form, where people give not because of what they can get in return, but because others need or want, and where there is an expectation of comparable

\footnotetext{
${ }^{7}$ Cohen, Why Not Socialism? 34.

${ }^{8}$ Ibid., 35.
} 


\section{BEYOND SUFFICIENCY}

generosity throughout society. ${ }^{9}$ This resembles the distributive principle of higher communism, where "society inscribe on its banners: from each according to his ability, to each according to his needs!" 10 Indeed, the influence of Marx is apparent in the fact that Cohen elsewhere describes the relationship between people under the Marxist principle in almost identical terms to how he describes it under communal reciprocity; the only significant difference is that the latter incorporates a caveat against free riding. ${ }^{11}$

However, communal reciprocity "is not strictly required for equality," despite its "supreme importance in the socialist conception."12 In other words, the community principle's second mode of caring is not a necessary condition of the restriction it places on regrettable choice and/or option luck inequalities. Rather, it is the principle's first mode of caring that primarily functions as the constraint. ${ }^{13}$ Cohen's description of it is somewhat underdeveloped. Interpretations are typically drawn from the following passage:

We cannot enjoy full community, you and I, if you make, and keep, say, ten times as much money as I do, because my life will then labor under challenges that you will never face, challenges that you could help me to cope with, but do not, because you keep your money. To illustrate. I am rich, and I live an easy life, whereas you are poor, because of regrettable choices and/or bad option luck, and not, therefore because of any lack of equality of opportunity. You have to ride the crowded bus every day, whereas I pass you by in my comfortable car. One day, however, I must take the bus, because my wife needs the car. I can reasonably complain about that to a fellow car-driver, but not to you. I can't say to you: "It's awful that I have to take the bus today." There is a lack of community between us of just the sort that

\footnotetext{
${ }^{9}$ Ibid., 38-45.

${ }^{10}$ Karl Marx, "Critique of the Gotha Programme," in Karl Marx: Selected Writings, ed. by David McLellan (Oxford: Oxford University Press, 1977), 569.

${ }^{11}$ Cohen on the Marxist principle: "Here the relationship between people is not the instrumental one in which I give because I get, but the wholly non-instrumental one in which I give because you need." This description is from G.A. Cohen, "Back to Socialist Basics," in On the Currency of Egalitarian Justice and Other Essays in Political Philosophy, ed. by Michael Otsuka (Princeton, NJ: Princeton University Press, 2011), 219. Cohen on communal reciprocity in Why Not Socialism? 43: "The relationship between us under communal reciprocity is not the marketinstrumental one in which I give because I get, but the noninstrumental one in which I give because you need, or want, and in which I expect a comparable generosity from you."

${ }^{12}$ Cohen, Why Not Socialism? 35.

${ }^{13} \mathrm{Ibid} ., 35$.
}

(c) 2018 Benjamin D. King

https://www.kritike.org/journal/issue 22/king june2018.pdf

ISSN 1908-7330

(c) BY-NC-ND 
naturally obtains between me and the fellow car-driver. And it will show itself in many other ways, for we enjoy widely different powers to care for ourselves, to protect and care for offspring, to avoid danger, and so on. ${ }^{14}$

Taking this passage together with what was established at the outset, it appears that Cohen views large inequalities of resources as problematic if they reflect people's regrettable choices and/or option luck, because considerable differences of economic power then typically amount to large inequalities of aggregate benefit, in the sense that the worst off face many more challenges in life than the best off. This outcome conflicts with community, as Cohen conceives it, because community involves people caring for each other to the extent that they share in a common life, understood as the lives of the worst off not laboring under significantly more challenges than those of the best off.

This interpretation is consistent with a second example provided almost immediately after the above passage. Imagine you are on a camping trip with Cohen and some mutual friends. Imagine further that you have access to a high-grade fishpond, which you won in a lottery that everyone entered, but that you selfishly decide not to share it. As a result, whilst you get fat on exorbitant amounts of fish, the rest of the group has little to eat. ${ }^{15}$ This large inequality of resources, which is due to option luck, conflicts with community, because community would involve the group caring for each other by sharing the pond. As Cohen says of the outcome, "even though there is no injustice here, your luck cuts you off from our common life, and the ideal of community condemns that, and therefore also condemns the running of any such lottery." 16

Contrary to an alternative interpretation, it is also the non-realization of a common life that is fundamental in the bus case. Nicholas Vrousalis thinks it is plausible to assume "that the idea of community at work in the passage above is, or partakes of, justificatory community." 17 The community principle's first mode of caring is, he says, "something like justificatory community." ${ }^{18}$ Cohen's concept of "justificatory community" is developed in his sustained critical engagement with Rawls, definitively presented in Rescuing Justice and Equality. It is realized when policy arguments pass "the

${ }^{14}$ Ibid., 35-36.

${ }^{15}$ Ibid., 37-38.

${ }^{16}$ Ibid., 38.

${ }_{17}$ Nicholas Vrousalis, "Jazz Bands, Camping Trips and Decommodification: G. A. Cohen on Community," in Socialist Studies, 8:1 (2012), 154. See also Nicholas Vrousalis, The Political Philosophy of G. A. Cohen: Back to Socialist Basics (London: Bloomsbury, 2015).

18 Vrousalis, “Jazz Bands, Camping Trips and Decommodification,” 156.

(C) 2018 Benjamin D. King

https://www.kritike.org/journal/issue 22/king june2018.pdf

ISSN 1908-7330

(cc) BY-NC-ND 


\section{BEYOND SUFFICIENCY}

interpersonal test," which "asks whether the argument could serve as a justification of a mooted policy when uttered by any member of society to any other member." 19

However, if the interpersonal test were employed in the bus case it would not obviously reveal a lack of justificatory community. Unlike in the case used to criticize the lax interpretation of Rawls' difference principle for licensing unequalizing incentive payments, where naturally talented individuals struggle to justify to the least-advantaged their intention to work less hard in the face of an income tax rise, the car-driver could justify his relative advantage to the bus-rider on the basis that it is responsibilitysensitive. ${ }^{20}$ It thus seems equally plausible to assume that the bus case is not meant to illustrate a lack of justificatory community; Richard Miller denies that Cohen's evocations of community in Why Not Socialism? concern it. ${ }^{21}$ Rather, what matters is that, unless the car-driver shares his greater resources with the bus-rider, considerable inequality of resources prevents them from sharing in a common life.22 The unreasonableness of the car-driver's complaint if it was uttered to the bus-rider, but not the fellow car-driver, is simply an illustration of the fact that the bus-rider faces significantly more challenges in life, and the corresponding improbability that she would empathize.

What Cohen finds repugnant about the worst off facing many more challenges than the best off, at least in cases where those challenges could be prevented or alleviated to the relevant degree (challenges of severe physical and/or mental impairment, for example, cannot always be prevented or so alleviated), is that it reflects a lack of caring and sharing. It is reasonably clear, given the above illustrations of its non-realization, that the community principle's first mode of caring involves people sharing resources to the extent that a common life obtains. For example, to invoke the beginning of the passage above, its realization would involve you not keeping all of your money if you earn, say, ten times as much as I do, but you instead sharing your greater resources with me, to the extent that I do not face considerably more challenges in life than you. It would involve rich car-drivers sharing their greater resources not merely to the end that buses cease to be overcrowded, but to the extent that there ceases to be rich car-drivers and poor bus-riders, since transport is only one example of how greatly different

\footnotetext{
Press, 2008), 42.

${ }^{20}$ For the former case, see ibid., 48-69.

${ }^{21}$ Richard W. Miller, "Relationships of Equality: A Camping Trip Revisited," in The Journal of Ethics, 14:3-4 (2010), 249.

${ }^{22}$ See ibid., 249-250; Pablo Gilabert, "Cohen on Socialism, Equality and Community," in Socialist Studies, 8:1 (2012), 105; Christine Sypnowich, “G. A. Cohen's Socialism: Scientific But Also Utopian," in Socialist Studies, 8:1 (2012), 27-28.
}

${ }^{19}$ G.A. Cohen, Rescuing Justice and Equality (Cambridge, MA: Harvard University

(c) 2018 Benjamin D. King

https://www.kritike.org/journal/issue 22/king june2018.pdf

ISSN 1908-7330

(c) ) BY-NC-ND 
economic power cuts people off from a shared common life. Condemnation of the fishpond lottery on the camping trip suggests it would also involve people avoiding option luck that could lead to the undesired state of affairs.

It is unclear whether the community principle's first mode of caring is voluntary or enforced. Miriam Ronzoni interprets it as voluntary and suggests that, in addition to resource sharing, it "might entail ... that the naturally talented freely choose to put their skills to the service of the community rather than of their own profit only." 23 This is a reference to Cohen's concept of an "egalitarian ethos," which also features in his critique of Rawls. But, as with justificatory community, we should be careful not to blur Cohen's ideas. The ethos contributes towards distributive justice by informing people's choices within society's coercive rules. For example, in Cohen's "doctor-gardener" illustration, it motivates a naturally talented individual who prefers gardening to doctoring for pay consistent with responsibility-sensitive equality, but doctoring to gardening at a certain rate of unequalizing incentives, to nevertheless refuse unequalizing incentives for doctoring, because if she accepted those incentives she would be acting contrary to her luck egalitarian belief that differences of natural ability fail to justify differences in people's distributive shares. ${ }^{24}$ Yet, as Jonathan Quong argues, contrary to how it is sometimes interpreted, in itself the egalitarian ethos "does not require talented people to choose any particular occupationit merely forbids talented people (subject to a limited agent-centered prerogative) from accepting unequalizing incentives for taking on socially optimal jobs." 25 Choosing those jobs whilst forgoing unequalizing incentives further requires the talented to internalize what Cohen variously speaks of as "an obligation to serve others," or "a desire to contribute to society," or a "sense of commitment to other people." 26 It is this productive ethos in combination with her luck egalitarianism that motivates doctor-gardener to make the socially optimal choice.

Is the productive ethos constitutive of the community principle? Possibly, but Cohen's descriptions of it appear to resemble communal reciprocity more than his illustrations of its first mode of caring. Moreover, the egalitarian-productive ethos is primarily intended as a means to ensure both distributive justice and efficiency without having to restrict freedom of occupational choice. The first mode of caring targets none of those ends. It is instead a means to the realization of a shared common life, from which people

\footnotetext{
${ }^{23}$ Miriam Ronzoni, "Life is not a camping trip - on the desirability of Cohenite socialism," in Politics, Philosophy \& Economics, 11:2 (2012), 173.

${ }^{24}$ See Cohen, Rescuiing Justice and Equality, 183-196. 327.

${ }^{25}$ Jonathan Quong, "Justice Beyond Equality," in Social Theory and Practice, 36:2 (2010),

${ }^{26}$ Cohen, Rescuing Justice and Equality, 190.
} 


\section{BEYOND SUFFICIENCY}

might nevertheless be cut off in a society whose members internalize the ethos, since a commitment to responsibility-sensitive equality and to performing socially optimal labor does not rule out large regrettable choice and/or option luck inequalities. A world in which doctor-gardener chooses doctoring consistent with a luck egalitarian pay scheme may nevertheless be a world in which she chooses to bet big on a throw of the dice, and, if she loses, perhaps comes to regret that choice.

What is clear is that the central requirement of the community principle "is that people care about, and, where necessary and possible, care for, one another, and, too, care that they care about one another." 27 This leaves open the possibility of democratically enforcing the constraint on inequality. First, note that people might care about one another, in the sense that they are concerned about one another's welfare, yet, where necessary and possible, not actually do anything to care for one another. Second, if people do care for one another, they might do so only because they are forced to, for example, through social welfare programs funded by general taxation. Third, people might care that they care about one another, and thus vote for forms of enforced caring, such as that just mentioned, or care for one another in an entirely noncoerced way, for example, by voluntarily sharing resources, or some combination of both. Communal reciprocity would also reflect this commitment to others, but, as noted previously, it is not a necessary condition of the constraint. The central requirement of the community principle does not therefore rule out a democratic decision to enforce its first mode of caring. As Pablo Gilabert notes, Cohen himself appears to envisage enforcement when he speaks of the community principle as "forbidding" the relevant inequalities. ${ }^{28}$

\section{The Abandonment Objection}

If the community constraint is voluntary, then the tendency for human beings to act selfishly is a significant practical problem. Unless resources are so abundant that people have no reason to compete for greater distributive shares, only moderate levels of selfishness render it probable that levels of voluntary resource sharing and abstinence from option luck would fall short of establishing a common life. More importantly, if it is voluntary, the constraint does not guarantee security against absolute forms of deprivation that might follow from people's imprudent decisions, since levels of voluntary caring might also fall short in that regard. A voluntary community constraint thus fails as a response to perhaps the most forceful

${ }^{27}$ Cohen, Why Not Socialism? 34-35.

${ }^{28}$ Gilabert, "Cohen on Socialism, Equality and Community," 109 n. 14; see Cohen, Why Not Socialism? 12, 37.

(c) 2018 Benjamin D. King

https://www.kritike.org/journal/issue 22/king june2018.pdf

ISSN 1908-7330

(c) $\mathrm{BY}-\mathrm{NC}-\mathrm{ND}$ 
"democratic egalitarian" objection to luck egalitarianism, which is that it denies some citizens the social conditions of their effective freedom by countenancing the "abandonment of negligent victims." 29 For those unfamiliar with this objection, consider the paradigm example of the uninsured reckless driver: 30

Imagine a person who, against a background of equal opportunities, makes a genuine choice to drive recklessly without health insurance. This person then goes on to have an accident that leaves her severely injured. If she receives expensive medical treatment she will make a full recovery, but she cannot afford to pay for it due to her lack of insurance, and the consequence of non-treatment would be severe physical and/or mental impairment. A strict luck egalitarian sees no distributive injustice in society not covering the costs, since the driver's misfortune is a case of bad option luck. Socialist equality of opportunity therefore permits the abandonment of imprudent people to absolute forms of deprivation, whether it is severe physical and/or mental impairment, as in cases such as this, or abject poverty, as in cases where people make genuine choices to gamble their income and wealth and lose to that end.

Abandoning especially imprudent people to deprivation would, of course, at least in a moderately wealthy society, cut them off from a shared common life with the better off. As we have seen, Cohen deems this outcome repugnant if it could be corrected by sharing resources, or if it could have been averted by avoidance of the gamble. Victims of bad option luck would not therefore be abandoned to absolute forms of deprivation in an ideal Cohenite socialist world where the community constraint is voluntarily implemented; although it is important to remember that in this world its implementation is not a requirement of justice, since Cohen understands the constraint as either "defin[ing] the terms within which justice will operate, or [as] ... sometimes (justifiably?) contradict[ing] justice." 31

But what if, as is more probable, selfishness thwarts the voluntary implementation of the community principle's first mode of caring? Cohenite socialists might insist that in this world their preferred socialism is unrealized, and so it cannot be criticized for abandoning negligent victims. However, despite Cohen's thesis that the principles at the summit of our normative beliefs do not respond to and are therefore not grounded in facts,

\footnotetext{
${ }^{29}$ See Elizabeth S. Anderson, "What Is the Point of Equality?" in Ethics, 109:2 (1999), 295-296; Samuel Scheffler, "What is Egalitarianism?" in Philosophy \& Public Affairs, 31:1 (2003), 18-19; Samuel Scheffler, "Choice, circumstance, and the value of equality," in Politics, Philosophy \& Economics, 4:1 (2005), 15.

30 See Anderson, “What Is the Point of Equality?" 295-296; Marc Fleurbaey, “Equal Opportunity or Equal Social Outcome," in Economics and Philosophy, 11:1 (1995), 40-41.

${ }^{31}$ Cohen, Why Not Socialism? 37.
} 


\section{BEYOND SUFFICIENCY}

the tendency for human beings to act selfishly is a fact that surely counts against a voluntary community constraint. ${ }^{32}$ After all, Cohen's aim is to defend both a desirable and feasible alternative to capitalism, which is why he too considers the problem of selfishness. As he understands it, the problem is not primarily one of human nature but of economic design, because "while we know how to make an economic system work on the basis of the development, and, indeed, the hypertrophy, of selfishness, we do not know how to make it work by developing and exploiting human generosity." 33 The feasibility of a voluntary community constraint given the probability of selfishness is therefore a valid consideration, and this consideration has implications for its desirability. It is undesirable under the probable conditions because it would not guarantee security against deprivation that is permitted by socialist equality of opportunity. In contrast, an economic design that includes enforcing that security, as the outcome of a democratic decision-making procedure that reflects communal caring, is both feasible and desirable.

An alternative strategy that might be employed by defenders of a voluntary community constraint is to argue that the abandonment objection reveals a problem with socialist equality of opportunity, whilst insisting that the community principle is not meant to solve that problem. On this view, the desirability of Cohenite socialism depends on revising its egalitarian principle rather than its community principle. However, the community principle's first mode of caring is, at least indirectly, meant to deal with the abandonment objection, for it seeks to mitigate the same inequalities that the objection highlights as unacceptable to leave unmitigated. Unless resources are particularly scarce, mitigating option luck inequalities to the extent that a shared common life obtains will provide the imprudent with enough to avoid deprivation, and if resources are moderately plentiful, it will allocate them significantly more than enough. For example, let us imagine that the situation of the campers who lose the fishpond lottery is so dire that they struggle to satisfy their basic needs of subsistence. If the campers, because they value a shared common life, had instead prohibited the lottery and agreed to common ownership of the pond, or if the lottery winner had instead sought to re-establish a common life after the fact by sharing the pond, an indirect consequence, assuming the fishpond is adequately to plentifully stocked, would be either the prevention of unnecessary suffering or the rescue of imprudent people from it. Hence, the community principle's first mode of caring is an indirect response to the abandonment objection, although one that is unsatisfactory if it is voluntary.

\footnotetext{
32 For the relevant thesis, see Cohen, Rescuing Justice and Equality, 232-233.

${ }^{33}$ Cohen, Why Not Socialism? 58.
} 
Contrary to Cohenite socialism, abandoning negligent victims to deprivation does not only seem objectionable because it reflects a lack of communal caring, it also seems intuitively unjust. If that intuition is not mistaken, it follows that luck egalitarianism is either an implausible or incomplete theory of distributive justice. In response to the abandonment objection, it is common to reach the latter conclusion and propose supplementing luck egalitarianism with a sufficiency principle that tempers its emphasis on responsibility. ${ }^{34}$ On this view, justice does not require holding people responsible for the consequences of their genuine choices if it means denying them a sufficient distributive share, but it does require distributive shares to be responsibility-sensitive above a guaranteed minimum. Paula Casal maintains that this mixed view of justice is not incoherent, as the intermittent role of responsibility in determining just shares can be explained by the fact that forbidding choice-generated inequality would require severe restrictions on liberty, whereas forbidding choice-generated insufficiency tends to require less costly restrictions on liberty. ${ }^{35}$

A particularly forceful justification of a sufficiency constraint, which is open to luck egalitarians to adopt, is to ground it in a liberal democratic interpretation of social contract theory. On this view, citizens are owed what they require to participate fully in a democratic society in return for consenting to the authority of the state, and they act collectively through the state to fulfill each person's entitlements. ${ }^{36}$ In Elizabeth Anderson's seminal theory of "democratic equality," this is fleshed out in terms of entitlements to capabilities necessary to avoid oppressive social relationships and for functioning as an equal citizen. Functioning as an equal citizen involves the ability to effectively exercise one's political rights and to participate in the various activities of civil society, which presupposes effective access to the means of subsistence and human agency. To illustrate, if one does not have sufficient food, clothes, shelter, healthcare, and an adequate education that enables her to make informed choices, she cannot effectively exercise her right to vote or to engage in public deliberation, nor can she participate as an equal in a system of cooperative production, nor might she have effective access to public transport, and thus to certain public spaces, nor might she

34 See Nicholas Barry, "Defending Luck Egalitarianism," in Journal of Applied Philosophy, 23:1 (2006); Alexander Brown, "Luck Egalitarianism and Democratic Equality," in Ethical Perspectives, 12:3 (2005); Paula Casal, "Why Sufficiency Is Not Enough," in Ethics, 117:2 (2007); Andrew Williams, "Liberty, Equality, and Property," in The Oxford Handbook of Political Theory, ed. by John S. Dryzek, Bonnie Honig and Anne Phillips (Oxford: Oxford University Press, 2006).

${ }^{35}$ Casal, "Why Sufficiency Is Not Enough," 322.

36 See Anderson, "What Is the Point of Equality?" 314-315; Barry, "Defending Luck Egalitarianism," 100.

(C) 2018 Benjamin D. King

https://www.kritike.org/journal/issue 22/king june2018.pdf

ISSN 1908-7330 


\section{BEYOND SUFFICIENCY}

even be able to appear in public without shame. ${ }^{37}$ Democratic equality thus "requires that everyone have effective access to enough resources to avoid being oppressed by others and to function as an equal in civil society." 38

Nevertheless, Cohenite socialists might insist that distributive justice does not require sufficiency, whilst still viewing the abandonment of imprudent people to deprivation repugnant on the basis that it reflects a lack of caring that cuts people off from a shared common life. Moreover, as the central requirement of the community principle does not rule out democratic enforcement of its first mode of caring, Cohenite socialists might opt for this measure given the undesirability of a voluntary community constraint in a selfish world. The problem, however, is that enforcing the community constraint appears to involve unjustified restrictions on liberty. This becomes evident after further distinguishing how it goes beyond sufficientarianism.

\section{The Liberty Objection}

The community constraint on luck egalitarianism varies in degree compared with a sufficiency constraint. Regarding the latter, it is plausible that everyone could have effective access to enough resources to avoid deprivation, oppression and to function as equal citizens in a democratic society that is characterized by large inequalities of resources. Inequalities of resources would be troubling for democratic equality if the consequence were that the ability of people to function as equal citizens were undermined, such as if the inequalities effectively enabled the wealthy to select candidates for public office. When democratic egalitarian concerns are built into a sufficiency constraint it might therefore require minding the gap. But it does not necessarily require it, since, on this view, "[t]he stronger the barriers against commodifying social status, political influence, and the like, the more acceptable are significant income inequalities." ${ }^{39}$ It therefore permits large inequalities of resources if the state successfully prevents their conversion into effectively unequal citizenship.

In contrast, the community constraint does necessarily require minding the gap, as it requires that the worst off do not face significantly more challenges in life than the best off. To emphasize the distinction. On the one hand, supplementing luck egalitarianism with a sufficiency constraint necessarily keeps responsibility-sensitive inequalities of resources within any range except where distributive shares at the bottom end of the scale are insufficient. On the other hand, supplementing luck egalitarianism with the community constraint necessarily keeps certain responsibility-sensitive inequalities of

\footnotetext{
${ }^{37}$ Anderson, “What Is the Point of Equality?" 316-321.

38 Ibid., 320.

${ }^{39}$ Ibid., 326.
}

(c) 2018 Benjamin D. King

https://www.kritike.org/journal/issue 22/king june2018.pdf

ISSN 1908-7330

(c) BY-NC-ND 
resources within a limited range where the top and bottom ends of the scale are narrowed by the goal of establishing a shared common life. For example, imagine that a tenfold income inequality exists between us, not because of any inequality of opportunity, but because of my regrettable choices and/or bad option luck. Your income is $\$ 350,000$ a year and my income is $\$ 35,000$ a year. If $\$ 35,000$ is sufficient for the satisfaction of my basic needs and for me to function as an equal citizen, the requirements of luck egalitarianism supplemented with a democratic egalitarian sufficiency constraint are satisfied. On the contrary, the requirements of Cohenite socialism are not satisfied. Other things equal, I will face significantly more challenges in life than you, due to the considerable difference in our economic power. If the community constraint were enforced your greater resources would instead be shared to the extent that I do not face many more challenges in life than you, or the inequality of resources would have never arisen because of restrictions on option luck, or some combination of both. The community constraint thus requires greater equalization of certain responsibilitysensitive inequalities of resources. It necessarily forbids large regrettable choice and/or option luck inequalities, whereas a sufficiency constraint does not.

Enforcing either constraint, to borrow terms from Andrew Williams, would require "internalizing" and/or "externalizing" of its costs. Internalizing costs would involve restricting people's liberty to participate in option luck, for example, by enforcing special taxes, compulsory insurance and/or prohibition of reckless activities, to the degree necessary to realize either sufficiency or a shared common life. Externalizing costs would instead involve spreading liability for people's regrettable choices and/or bad option luck across society by means of general taxation, again, to the degree necessary to realize either constraint. ${ }^{40}$

Internalizing and externalizing the costs of a sufficiency constraint on luck egalitarianism can be justified on the contractualist grounds explained above. Of the two methods of enforcement, internalizing might be preferable to externalizing, since externalizing the costs of sufficiency would involve, if not injustice, at least unfairness. That is to say, even if justice requires sufficiency, when differences of outcome reflect only people's genuine choices made against a background of equal opportunities, there is nevertheless an unfairness involved in forcing prudent people to bear the costs of correcting for imprudent people's insufficiency. That is not to say, however, that externalizing the costs of sufficiency is unjustified. As it might be preferable, all things considered, to collectively fulfill each person's entitlements by spreading liability for people's regrettable choices and/or bad

${ }^{40}$ Williams, “Liberty, Equality, and Property," 501-502.

(C) 2018 Benjamin D. King

https://www.kritike.org/journal/issue 22/king june2018.pdf

ISSN 1908-7330

(cc) BY-NC-ND 


\section{BEYOND SUFFICIENCY}

option luck across society, rather than restrict people's liberty to participate in option luck, or some combination of both.

In contrast, both internalizing and externalizing the potentially greater costs of the community constraint on luck egalitarianism seems unjustified. Consider again the case above where a tenfold responsibilitysensitive income inequality cuts us off from a shared common life, but where my income is sufficient. Should the state have forbidden this outcome by internalizing the costs of the community constraint? That is to ask, should we have collectively placed restrictions on our liberty to participate in option luck, for example, by enforcing special taxes, compulsory insurance and/or prohibition of reckless activities to the necessary degree? Whereas restrictions on liberty of this sort can be justified if they are necessary, which they are not in this case, to the degree required to guarantee our sufficiency, it is doubtful whether the possibility of one of us having to face many more challenges in life than the other justifies further restrictions. Remember, the difference of outcome reflects only our genuine choices made against a background of equal opportunities. Thus, so long as our choices did not have the potential to generate insufficiency, and did not, therefore, risk the unfairness involved in having to externalize the costs of sufficiency, we have strong claims against others restricting our liberty to make those choices. In cases where large inequalities of resources are responsibility-sensitive, and where internalizing the costs of a shared common life necessitates more severe restrictions on liberty than what is required to secure people's sufficiency, those greater restrictions appear unjustified.

But what about externalizing the costs for us to share in a common life? Should we instead have acted collectively to forbid the tenfold income inequality that separates us by such means? Suppose that for me not to face significantly more challenges in life than you would require redistributing $\$ 100,000$ by means of taxation, so that my income increases from $\$ 35,000$ to $\$ 135,000$ a year, and your income decreases from $\$ 350,000$ to $\$ 250,000$ a year. Similar to the problem with internalizing the community constraint, whereas taxing you can be justified if it is necessary, which it is not in this case, to externalize the costs of my sufficiency, it is doubtful whether the mere fact that I would otherwise have to face many more challenges in life than you justifies further redistributive taxation. Indeed, I appear to have no claim whatsoever to even a small amount of your greater resources, let alone a substantial cut of your income, as I have sufficient resources and it is reasonable to hold me responsible for my relative disadvantage. Thus, in cases where large inequalities of resources are responsibility-sensitive, and where externalizing the costs of a shared common life necessitates redistributive taxation beyond what is required to secure people's sufficiency,

(c) 2018 Benjamin D. King

https://www.kritike.org/journal/issue 22/king june2018.pdf

ISSN 1908-7330

(c) $)$ BY-NC-ND 
any further redistributive taxation seems an unjustified restriction on people's liberty over the use of their resources.

In response to "the liberty objection," it might be argued that I have misinterpreted the community principle's first mode of caring. This response targets and denies the distinction I have drawn between its radically egalitarian requirements and the more moderate sufficientarian requirements of democratic egalitarianism. On this view, the first mode of caring should be interpreted as some kind of sufficiency constraint, which does not therefore require the demanding equalization of resources and apparently unjustified restrictions on liberty outlined above.

Gilabert explores a sufficientarian account of the community principle. Contrary to Cohen's view that the restrictions it places on large inequalities either define the scope of justice or contradict it, he suggests we ought to view them as "more stringent demands of justice ... focused on sufficientarian concerns with basic needs and on requirements to protect equal political status and self-respect." ${ }^{41}$ I agree that this is a more plausible constraint on luck egalitarianism, but it is a reconstruction of the community principle. On Cohen's view the community principle is not a requirement of justice, and realization of its first mode of caring would involve more than addressing these sufficientarian concerns. As Gilabert agrees, people committed to the first mode of caring "would feel that their communal bonds are weakened if some of them turn out to face many more challenges in their lives than others due to significant inequalities of income and other material advantages." 42 Thus, unlike a sufficiency constraint, which does not necessarily prohibit this outcome, establishing a shared common life by enforcing the first mode of caring requires that we mind the gap. The interpretation of the community constraint that understands it as necessarily restricting large regrettable choice and/or option luck inequalities is most consistent with Cohen's view, and supplementing luck egalitarianism by enforcing that constraint appears to require unjustified restrictions on liberty.

\section{Equality, Sufficiency, and Community}

One solution to both objections is, of course, to reject Cohenite socialism in favor of some version of sufficiency-constrained luck egalitarianism. However, an alternative solution is to specify that the community principle's first mode of caring requires enforcement of sufficiency, but only voluntary equalization of resources thereafter, if it is necessary to establish a shared common life. The community constraint

${ }^{41}$ Gilabert, "Cohen on Socialism, Equality and Community," 103.

42 Ibid., 105.

(C) 2018 Benjamin D. King

https://www.kritike.org/journal/issue 22/king june2018.pdf

ISSN 1908-7330

(cc) BY-NC-ND 


\section{BEYOND SUFFICIENCY}

would not then fail to guarantee sufficiency or unjustifiably restrict liberty. Consistent with democratic egalitarianism and Gilabert's reconstruction, its enforced component should be rebuilt as a requirement of justice, whilst its voluntary component should be understood in terms of acts of caring that go beyond justice, and which reflect the broader requirements of community that Cohen envisions. As Gilabert appreciates, sufficientarian concerns do not exhaust requirements of community, and not all requirements of community are requirements of justice. ${ }^{43}$

A remaining issue is whether there is any compelling reason to prefer supplementing luck egalitarianism with this version of the community constraint to a purely sufficientarian alternative. This is beyond the scope of the article, but I shall nevertheless finish by noting two possibilities that are perhaps worthy of further reflection.

The first possible reason to prefer it, which is implicit in the bus case, concerns the increased opportunities for empathy provided by a shared common life. Assuming people are more likely to empathize with one another when they encounter similar experiences, and that empathy fosters communal caring that helps people to overcome challenges, it follows that society loses in that respect when its members have very different experiences because of considerable differences in their economic power. If it serves as a means to the creation and reinforcement of a more caring society, perhaps even a society that is characterized by communal reciprocity or the Marxist needs principle, pursuing a shared common life through voluntary resource sharing and/or refraining from option luck might therefore be preferable to settling only for sufficiency-constrained luck egalitarianism.

The second possible reason invokes "the priority view," but only as a view about what would be morally good and not as a view about what justice requires. The basic view is that equal improvements in a person's welfare have greater moral value the worse off a person is in absolute terms, so that we ought to give priority to improving the welfare of the worst off, whilst perhaps allowing that at some stage small gains in welfare for the worst off do not outweigh the moral value of large gains (or avoiding large loses) in welfare for the better off. ${ }^{44}$ Accordingly, the voluntary pursuit of a shared common life might be preferable to settling only for the enforcement of distributive justice, that is, sufficiency-constrained luck egalitarianism, if it serves as a means to improve the lifetime welfare of the worst off, and if those gains outweigh the moral value of avoiding the losses in lifetime welfare shouldered by the better off.

${ }^{43}$ Ibid., 108.

${ }^{44}$ Derek Parfit, "Equality or Priority?" in The Ideal of Equality, ed. by Matthew Clayton and Andrew Williams (Basingstoke: Palgrave Macmillan, 2002), 101, 105.

(c) 2018 Benjamin D. King

https://www.kritike.org/journal/issue 22/king june2018.pdf

ISSN 1908-7330

(cc) BY-NC-ND 
However, the moral importance of empathy motivated altruism and of improving the lifetime welfare of the worst off is greatly diminished when the worst off enjoy and are guaranteed sufficiency, and when the relative disadvantage they experience above that threshold is responsibility-sensitive. Thus, even if there are reasons to prefer the specified community constraint to a purely sufficientarian alternative, I am somewhat skeptical about the force of the noted possibilities. ${ }^{45}$

Institute of Diplomacy and International Studies, Rangsit University, Thailand

\section{References}

Anderson, Elizabeth S., "What Is the Point of Equality?" in Ethics, 109:2 (1999). Barry, Nicholas, "Defending Luck Egalitarianism," in Journal of Applied Philosophy, 23:1 (2006).

Brown, Alexander, "Luck Egalitarianism and Democratic Equality," in Ethical Perspectives, 12:3 (2005).

Casal, Paula, "Why Sufficiency Is Not Enough," in Ethics, 117:2 (2007).

Cohen, G.A., "Back to Socialist Basics," in On the Currency of Egalitarian Justice and Other Essays in Political Philosophy, ed. by Michael Otsuka (Princeton, NJ: Princeton University Press, 2011). "On the Currency of Egalitarian Justice," in Ethics, 99:4 (1989). Rescuing Justice and Equality (Cambridge, MA: Harvard University Press, 2008). Why Not Socialism? (Princeton, NJ: Princeton University Press, 2009).

Dworkin, Ronald, "What is Equality? Part 2: Equality of Resources," in Philosophy and Public Affairs, 10:4 (1981).

Fleurbaey, Marc, "Equal Opportunity or Equal Social Outcome," in Economics and Philosophy, 11:1 (1995).

Gilabert, Pablo, "Cohen on Socialism, Equality and Community," in Socialist Studies, 8:1 (2012).

Knight, Carl, "Luck Egalitarianism," in Philosophy Compass, 8:10 (2013).

Marx, Karl, "Critique of the Gotha Programme," in Karl Marx: Selected Writings, ed. by David McLellan (Oxford: Oxford University Press, 1977).

45 This article draws from and substantially revises a chapter of my $\mathrm{PhD}$ thesis, which was completed at the University of Warwick. I am indebted to my supervisors, Matthew Clayton, Andrew Mason and Zofia Stemplowska for their guidance, support and helpful comments on earlier drafts. I also wish to thank my examiners, Adam Swift and Andrew Williams. Lastly, I am grateful to the UK's Economic and Social Research Council for generously funding my doctorate (award reference 1105321).

(C) 2018 Benjamin D. King

https://www.kritike.org/journal/issue 22/king june2018.pdf

ISSN 1908-7330 


\section{BEYOND SUFFICIENCY}

Miller, Richard W., "Relationships of Equality: A Camping Trip Revisited," in The Journal of Ethics, 14:3-4 (2010).

Parfit, Derek, "Equality or Priority?" in The Ideal of Equality, ed. by Matthew Clayton and Andrew Williams (Basingstoke: Palgrave Macmillan, 2002).

Quong, Jonathan, "Justice Beyond Equality," in Social Theory and Practice, 36:2 (2010).

Ronzoni, Miriam, "Life is not a camping trip - on the desirability of Cohenite socialism," in Politics, Philosophy \& Economics, 11:2 (2012).

Scheffler, Samuel, "Choice, circumstance, and the value of equality," in Politics, Philosophy \& Economics, 4:1 (2005).

"What is Egalitarianism?" in Philosophy \& Public Affairs, 31:1 (2003).

Sypnowich, Christine, "G. A. Cohen's Socialism: Scientific But Also Utopian," in Socialist Studies, 8:1 (2012).

Vrousalis, Nicholas, “Jazz Bands, Camping Trips and Decommodification: G. A. Cohen on Community," in Socialist Studies, 8:1 (2012).

The Political Philosophy of G. A. Cohen: Back to Socialist Basics. (London: Bloomsbury, 2015).

Williams, Andrew, "Liberty, Equality, and Property," in The Oxford Handbook of Political Theory, ed. by John S. Dryzek, Bonnie Honig and Anne Phillips (Oxford: Oxford University Press, 2006). 